\title{
Admonishing the Doubting Flock
}

Review of Francis Fukuyama's Book “Identity: The Demand for Dignity and the Politics of Resentment"

\author{
Alexei I. Miller
}

Identity. The demand for dignity and the politics of resentment. New York: Farrar, Straus and Giroux, 2018

Almost twenty years ago Rogers Brubaker and Frederick Cooper published an article that became a classic (Brubaker R., Cooper F. Beyond "Identity" // Theory and Society. \#1 (2000). P. 1-47). Here is what the authors said at the beginning of the article: "The argument of this article is that the social sciences and humanities have surrendered to the word 'identity'; that this has both intellectual and political costs; and that we can do better. 'Identity, we argue, tends to mean too much (when understood in a strong sense), too little (when understood in a weak sense), or nothing at all (because of its sheer ambiguity)...

"'Soft' constructivism allows putative 'identities' to proliferate. But as they proliferate, the term loses its analytical

\footnotetext{
Alexei I. Miller

European University at Saint-Petersburg, Russia

Department of History

Professor;

European University at Saint-Petersburg. Russia

Center for the Study of Cultural Memory and Symbolic Politics

Academic Director
}

ResearcherID: Z-1451-2019

Scopus AuthorID: 56321369000

Тел: +7 (812) 386-7634

E-mail: amiller@eu.spb.ru

Address: European University at St. Petersburg, 6/1A Gagarinskaya Street, 191187 St. Petersburg, Russia. 
purchase. If identity is everywhere, it is nowhere... 'Identity' is a key term in the vernacular idiom of contemporary politics, and social analysis must take account of this fact. But this does not require us to use 'identity' as a category of analysis or to conceptualize 'identities' as something that all people have, seek, construct, and negotiate. Conceptualizing all affinities and affiliations, all forms of belonging, all experiences of commonality, connectedness, and cohesion, all self-understanding and selfidentification in the idiom of 'identity' saddles us with a blunt, flat, undifferentiated vocabulary."

There are several reasons why this quote is important for evaluating Francis Fukuyama's book "Identity: The Demand for Dignity and the Politics of Resentment." First of all, it clearly shows that "identity politics" was quite trendy at the beginning of the century, and the notion of 'identity' was so much abused in social sciences that Brubaker and Cooper had to remind everyone that it did not explain much but rather needed some clarification itself.

Secondly, having found out that this article, its admonitions and questions were ignored in Fukuyama's book, we can say with confidence that this is not a scholarly text but a piece of writing intended for a broad audience. Its genre can be compared in the Russian context with
Yekaterina Shulman's or Valery Solovei's essays. For this reason we shall give up the idea of writing a critical scholarly review of this book as inappropriate.

In a nutshell, Fukuyama's argument is as follows:

"Individuals throughout human history have found themselves at odds with their societies. But only in modern times has the view taken hold that the authentic inner self is intrinsically valuable, and the outer society systematically wrong and unfair in its valuation of the former. It is not the inner self that has to be made to conform to society's rules, but society itself that needs to change.

"... what was to become the modern concept of identity emerged only as societies started to modernize a few hundred years ago. While it originated in Europe, it has subsequently spread and taken root in virtually all societies around the globe.

“... The modern concept of identity unites three different phenomena. The first is thymos, a universal aspect of human personality that craves recognition. The second is the distinction between the inner and the outer self, and the raising of the moral valuation of the inner self over outer society. This emerged only in early modern Europe. The third is an evolving concept of dignity, in which recognition is due not just to a 


\section{Review}

narrow class of people, but to everyone. The broadening and universalization of dignity turns the private quest for self into a political project. In Western political thought, this shift took place in the generation after Rousseau, through the philosophers Immanuel Kant and particularly Georg Wilhelm Friedrich Hegel.

“...Contemporary identity politics is driven by the quest for equal recognition by groups that have been marginalized by their societies. But that desire for equal recognition can easily slide over into a demand for recognition of the group's superiority. This is a large part of the story of nationalism and national identity...

“...The impulses evident in the early stages of the Arab Spring and in the color revolutions point to what is the moral core of modern liberal democracy. Such regimes are based on the twin principles of freedom and equality.

"...Modern liberal democracies promise and largely deliver a minimal degree of equal respect..."

Fukuyama backs his theses with a variety of examples from different parts of the world, the essence of which is usually stated in one or two phrases, thus clearly indicating the author's superficial understanding of the processes unfolding there. It is important, though, that all of them should cite examples of identity politics. Here is a typical example of such "analysis": "A person living in Barcelona who suddenly realizes her real identity is Catalan rather than Spanish is simply excavating a lower layer of social identity that has been laid down beneath the one nearer to the surface." (Trust me; this is all the author can say on the matter!)

History is of no importance. In other words, it is seen as a "completely clear" and purely Western-centric oneway movement: "While it originated in Europe, it has subsequently spread and taken root in virtually all societies around the globe". The concept of modernization, with its shameless Western centrism and triumphalism of liberal democracy, has now been complemented with "identity history", which Fukuyama views as a function of modernization. Some fifty years ago, even the advocates of the theory of modernization had to admit that it was not working in its original form because it failed to take into account the sociocultural peculiarities of different societies. But for Fukuyama one explanation fits all: "This is what drove Americans to protest during the civil rights movement, South Africans to stand up against apartheid, Mohamed Bouazizi to immolate himself, and other protesters to risk their lives in Yangon, Burma, or in the Maidan or 
Tahrir Square, or in countless other confrontations over the centuries."

History, the end of which Fukuyama predicted some time ago with a big commercial success, has simply been negated by suggesting that interaction mechanisms concerning "identity" do not change over centuries. "Hans's personal story was characterized by the nineteenth-century social theorist Ferdinand Tönnies as the shift from Gemeinschaft to Gesellschaft, or from (village) community to (urban) society. It was experienced by millions of Europeans during the nineteenth century and is now happening in rapidly industrializing societies such as China and Vietnam." Let's forget the fact that the Gemeinschaft concept is quite applicable to Greek polis and even medieval cities. But can one really say that the movement of people from rural areas to cities in the contemporary world with its television and the Internet proceeds in the same way it did in 19th century Europe when it went through the process of alphabetization (eradication of illiteracy)?

It is no wonder that to Fukuyama the main authority among the researchers of nationalism is Ernest Gellner, an extremely schematic radical modernist who sincerely believed that there was correct civic nationalism in Western countries and incorrect, ethnic nationalism in other parts of the world. Fukuyama himself seems to believe this. In fact, the history of ideas is portrayed in his book in a very old-fashioned manner as a story telling about how a certain idea traveled through centuries from one bright mind to another, even brighter one, and makes a meaningful observation that Luther, Rousseau, Kant, and Hegel understood dignity differently.

The book should be judged by the law of the genre, that is, by trying to understand what exactly the politically motivated public intellectual wants to tell his readers and why. And what kind of readers? The text is addressed to people who believe in liberal democracy but who have become hesitant under the impression of recent events. Fukuyama considers many examples where things do not go the way they should. In his opinion, the reason for this is that the principles of liberal democracy have been buried in oblivion or because backward tribes and "populists" have failed to understand these principles. The most painful and difficult questions about how well liberal democracy has adapted to the new conditions and where it has lost the ability for critical reflection have been left out.

When giving his political recommendations in the end, Fukuyama has to admit that they 


\section{Review}

cannot be implemented in practice. So, We will not escape from thinking about his conclusion sounds like admonition ourselves and our society in identity to the flock that is living through hard terms. But we need to remember that times: the identities dwelling deep inside us

"We can imagine better places to be are neither fixed nor necessarily given in, which take account of our societies' to us by our accidents of birth. Identity increasing diversity, yet present a vision can be used to divide, but it can and has for how that diversity will still serve also been used to integrate. That in the common ends and support rather end will be the remedy for the populist than undermine liberal democracy. politics of the present."

Identity is the theme that underlies As is often the case with sermons, many political phenomena today, from this conclusion sounds quite trivial new populist nationalist movements, to and absolutely "unscientific," but Islamist fighters, to the controversies nothing can prevent those wishing to taking place on university campuses. believe in it. 